\title{
Severe Multi-Resistant Pemphigus vulgaris: prolonged remission with a single cycle of Rituximab*
}

\author{
Pênfigo vulgar grave Multirresistente: controle prolongado com um \\ único ciclo de Rituximabe
}

\author{
Isabela Soubhia Corral ${ }^{1}$ \\ Daniella Abbruzzini S. Koller ${ }^{4}$ \\ Thais Helena Proença de Freitas ${ }^{2}$ \\ Maria Elisa Ruffolo Magliari ${ }^{5}$
}

\author{
Renata Telles Rudge de Aquino ${ }^{3}$ \\ Helena Muller ${ }^{6}$
}

DOI: http://dx.doi.org/10.1590/abd1806-4841.20131990

\begin{abstract}
Pemphigus vulgaris is an autoimmune bullous disease whose therapy is based on systemic corticosteroids, with or without immunosuppressants. Rituximab is a chimeric monoclonal antibody of the IgG class, directed at a specific CD20 B cell surface antigen, used in pemphigus vulgaris empirically since 2002, with success in $90 \%$ of the cases and long periods of remission. Male patient, 33 years old, diagnosed with pemphigus vulgaris, confirmed by histopathology and direct immunofluorescence. He was treated for seven months with numerous treatments, including immunosuppressive drugs, with an unsatisfactory response, until he had complete remission with the use of rituximab. During a 34-month follow-up period, the patient presented a slight clinical relapse, which was successfully controlled with prednisone in a daily dose of $120 \mathrm{mg}$, soon reduced to $20 \mathrm{mg}$.
\end{abstract}

Keywords: Desmogleins; Drug resistance; Pemphigus; Treatment failure

Resumo: Pênfigo Vulgar é uma doença bolhosa auto-imune, cuja terapêutica é baseada em corticoesteróides sistêmicos, associados ou não a imunossupressores. Rituximabe é um anticorpo monoclonal quimérico da classe IgG direcionado a um antígeno CD20 de superfície celular específico da célula B, usado em pênfigo vulgar desde 2002, com sucesso em 90\% e longos períodos de remissão. Paciente masculino, 33 anos, diagnóstico de pênfigo vulgar, confirmado por histopatologia e imunofluorescência direta. Durante 7 meses, recebeu inúmeros tratamentos com imunossupressores, apresentando resposta insatisfatória e progressão da doença, até que logo após a introdução de rituximabe teve completa remissão. Durante um acompanhamento de 34 meses, apresentou leve recidiva clínica, controlada com prednisona $120 \mathrm{mg} /$ dia, rapidamente reduzida e em uso atual de Prednisona 20mg/dia.

Palavras-chave: Desmogleínas; Falha de tratamento; Pênfigo; Resistência a medicamentos

\section{INTRODUCTION}

Pemphigus vulgaris is an autoimmune bullous, potentially life-threatening disease, characterized by the presence of autoantibodies against desmosomal cadherins such as desmogleins 1 and 3. Therapeutic strategies rely on the use of systemic corticosteroids alone or in conjunction with other immunosuppressant drugs such as azathioprine, mycophenolate mofetil, methotrexate, cyclophosphamide or immunomodulators like dapsone or intravenous immunoglobulin. ${ }^{1,2}$

Received on 16.07.2012.

Approved by the Advisory Board and accepted for publication on 30.08.2012.

* Work performed at the Medicine Department and Dermatology Clinic at the Santa Casa de Misericórdia de São Paulo - São Paulo (SP), Brazil.

Conflict of interest: None

Financial funding: None

Dermatologist - MD at the Dermatology Clinic at Santa Casa de Misericórdia de São Paulo - São Paulo (SP), Brazil.

MD, MSc in Dermatology at the Federal University of São Paulo (UNIFESP). Voluntary physician at the Dermatology Clinic at Santa Casa de Misericórdia de São Paulo - São Paulo (SP), Brazil.

3 MD, PhD in general medicine at the Faculdade de Ciências Médicas da Santa Casa de Misericórdia de São Paulo (FCMSCMSP) - Voluntary physician at the Medicine Department at the Faculdade de Ciências Médicas da Santa Casa de Misericórdia de São Paulo (FCMSCMSP) - São Paulo (SP), Brazil.

4 Dermatologist - MD, voluntary physician at the Dermatology Clinic at Santa Casa de Misericórdia de São Paulo - São Paulo (SP), Brazil.

5 MD, MSc in General Medicine at the Medicine Department at the Faculdade de Ciências Médicas da Santa Casa de Misericórdia de São Paulo (FCMSCMSP) - Professor of general medicine at the Medicine Department at the Faculdade de Ciências Médicas da Santa Casa de Misericórdia de São Paulo (FCMSCMSP) - São Paulo(SP), Brazil.

6 Pathologist MD, Assistant Professor at the Pathological Sciences Department at the Faculdade de Ciências Médicas da Santa Casa de Misericórdia de São Paulo (FCMSCSP) - São Paulo (SP), Brazil. 
Rituximab is a chimeric monoclonal antibody of the IgG class, directed at a specific CD20 B-cell surface antigen. The effect of the drug on B-cell depletion stimulated its widespread use in a great variety of autoimmune diseases. In 1997, it was approved by the FDA for use in the treatment of non-Hodgkin's lymphomas and autoimmune diseases such as rheumatoid arthritis. In 1998, Anvisa approved rituximab for the same indications. ${ }^{1-5}$ The first report of rituximab in the treatment of pemphigus was publish in 2002 and many studies since have shown favorable results, specially in patients that did not respond to classic or conventional treatments previously. ${ }^{3}$

The drug links to the CD20 receptors, expressed on the auto-reactive B-lymphocytes membranes, resulting in their destruction, with subsequent diminished anti-desmoglein autoantibodies production. In cases in which relapse occur, a new increase in the level of such antibodies was demonstrated. ${ }^{5}$

\section{CASE REPORT}

Male patient, 33 years-old, without any morbid antecedents of notice, was admitted to the hospital with a history of painful bullous lesions on the scalp and oral cavity since two months before, with subsequent dissemination to the entire body. Physical examination showed flaccid blisters, mostly with serous content, besides exulcerated lesions covered in honey-colored crusts. (Figure 1) The diagnostic hypothesis was pemphigus vulgaris, later confirmed by skin biopsies and direct immunofluorescence. Treatment with prednisone $1 \mathrm{mg} / \mathrm{Kg} /$ day and antibiotics to address the secondary infection was then started. The patient was released 15 days later, with a slightly improved clinical condition.

He returned 10 days later, due to the appearance of new blisters, worsening of the pain and odynophagia. The dose of corticoid was increased to $1.5 \mathrm{mg} / \mathrm{Kg} /$ day, and both sulfone $100 \mathrm{mg} /$ day and systemic antibiotics were added to the treatment. As the patient's clinical condition rapidly deteriorated, sulfone was replaced by azathioprine $150 \mathrm{mg} /$ day and the dose of prednisone was once again increased to $2 \mathrm{mg} / \mathrm{Kg} /$ day. Despite these actions, there was a decline in the patient's general condition, and a worsening of the cutaneous lesions, accompanied by the development of thrombocytopenia secondary to the use of azathioprine. In a period of 20 days, the patient had almost $100 \%$ of his body surface stricken by the disease, including all mucosae (oral, nasal, ocular, penile, anal) and the periungual regions of all fingers and toes. He was then submitted to intravenous methylprednisolone pulse therapy in a dose of $1 \mathrm{~g} /$ day for 5 days. A week after the pulse therapy, new lesions were still appearing, leading to the intro- duction of five cycles of intravenous immunoglobulin at $400 \mathrm{mg} / \mathrm{Kg} /$ per cycle. After 75 days of hospitalization, the patient was discharged with an improved clinical condition.

One month after being discharged, the patient had a clinical relapse, with the appearance of new bullous lesions despite the daily use of prednisone $2 \mathrm{mg} / \mathrm{Kg}$. A new cycle of intravenous immunoglobulin was performed, followed by a second pulse therapy with methylprednisolone and the addition of mycophenolate mofetil $3 \mathrm{~g} /$ day for 30 days. However, mycophenolate mofetil was suspended due to Kaposi varicelliform eruptions, which were treated with intravenous acyclovir (Figure 2).

The persisting lack of clinical response resulted in the use of cyclophosphamide pulse therapy at $250 \mathrm{mg} /$ day, associated to dexamethasone 100 $\mathrm{mg} /$ day for 3 days. As the patient was still unresponsive, weekly intravenous treatment with rituximab $375 \mathrm{mg} / \mathrm{m} 2$ (4 cycles) was started. The patient presented with improvement of the cutaneous lesions after the first cycle and a complete remission in 20 days, being discharged with a prescription of prednisone 2 $\mathrm{mg} / \mathrm{Kg} /$ day and cyclophosphamide $50 \mathrm{mg} /$ day (Figure 3). These medications were progressively withdrawn and the patient was asymptomatic for 23 months using only low dosage corticoids ( $5 \mathrm{mg} /$ day). After this period there was a slight clinical relapse, which was controlled with prednisone $120 \mathrm{mg}$ /day, resulting in rapid regression of the disease. Presently, after 34 months of follow-up, the patient is being treated only with prednisone $20 \mathrm{mg}$ /day (Figure 4 ).

\section{DISCUSSION}

It has already been demonstrated that, rituximab - an anti-CD20 monoclonal antibody -induces a rapid and specific B-lymphocyte $\mathrm{CD} 20+$ peripheric depletion, thus acting on the main effector pathway of pemphigus vulgaris (pathogenic antibodies produced by B cells), without causing unspecific immunosuppressive responses, as observed with conventional therapy (systemic corticoids and other immunosuppressants). Furthermore, treatment with rituximab leads to a rapid decline in the plasma levels of IgG4 anti-desmoglein-3 and anti-desmoglein-1, which correlates directly with clinical remission..$^{1-6}$

First used on a bullous pemphigoid associated to non-Hodgkin's lymphoma in 1999, this drug was proven to be effective on pemphigus vulgaris, inducing long remissions and high rates of partial or total response $(90-95 \%)$. It has become a therapeutic alternative for patients that are refractory to conventional treatments or those presenting with severe adverse events secondary to systemic corticoids or immunosuppressants, and thus far, due to its high costs and 


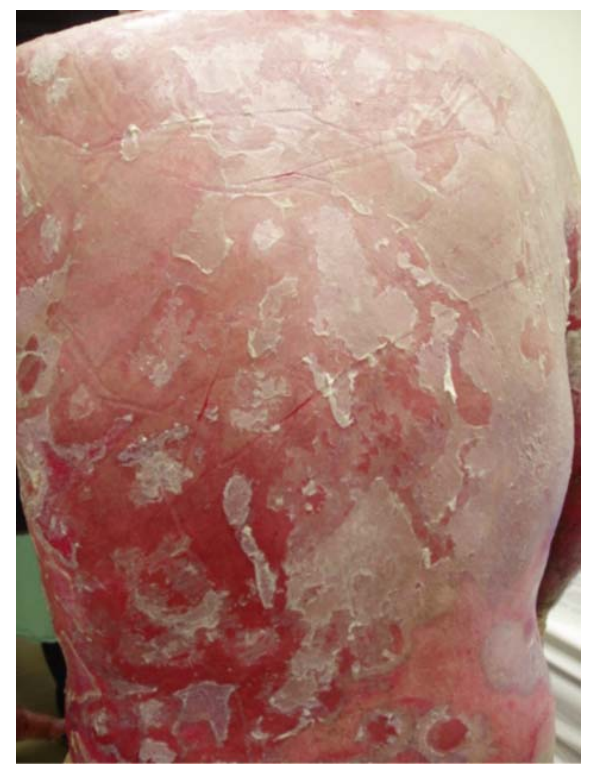

FIGURE 1:

01/05/2009 -

Before rituximab

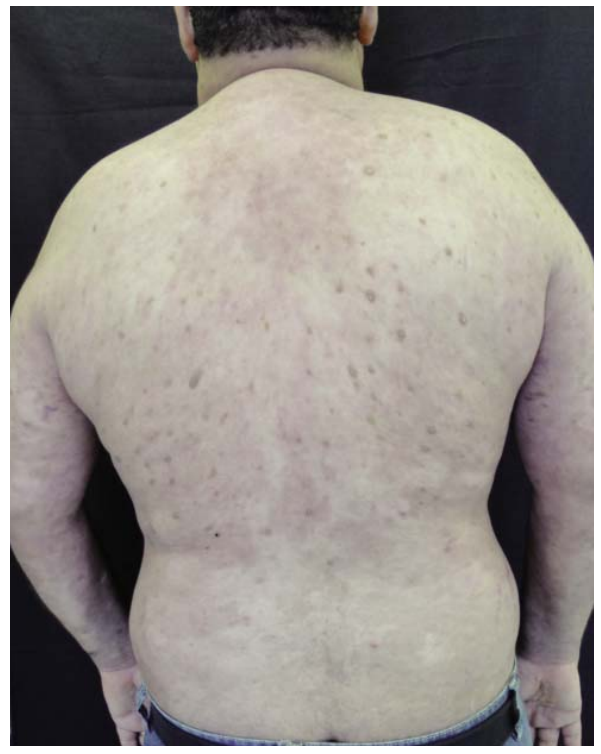

Figure 3:

03/02/2010- 3

months after

rituximab

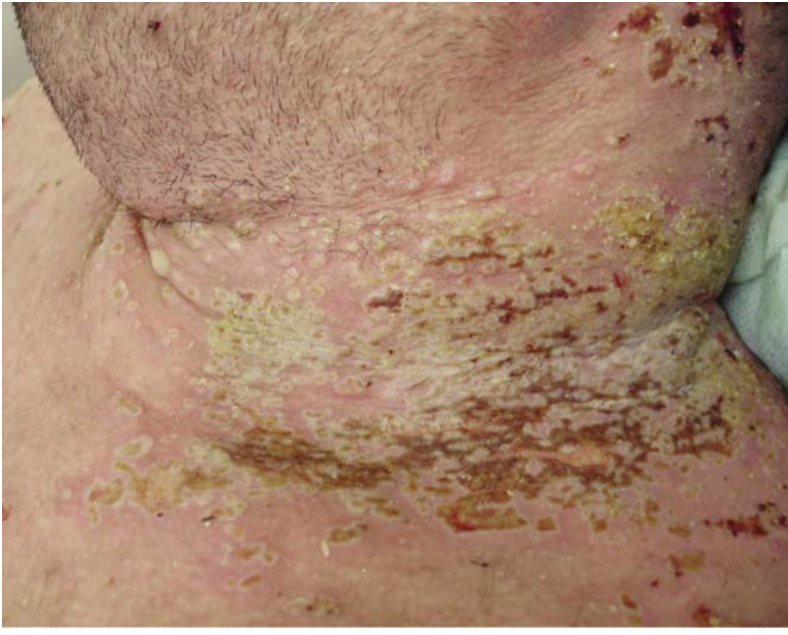

FIGURE 2: 10/09/2009 - Kaposi varicelliform eruption

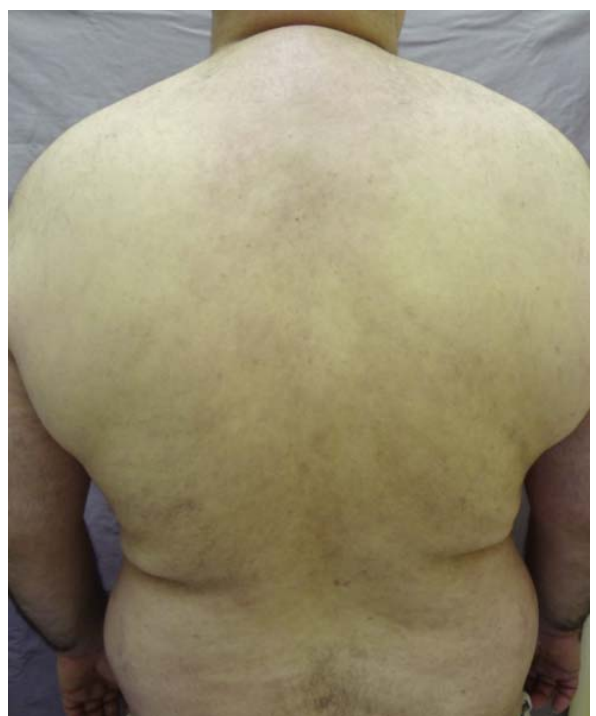

FIGURE 4:

$20 / 07 / 2012-$

34 months

after rituximab lack of evidence on long-term effects, rituximab should be reserved only for such patients. However, Hertl et al. discussed the possibility that rituximab might become the drug of choice in the treatment of generalized pemphigus, since the long-term remissions would minimize the impact of its high costs on the healthcare budget. In the case reported here, the early use of rituximab might have diminished the hospitalization time, which was 7 months in total, and also mitigated the various complications secondary to the use of corticoids and immunosuppressants..$^{2,7-10}$
Rituximab has a good safety profile up to 3 years of follow-up, and its adverse events are mostly mild and transitory: nausea, vomiting, chills, urticaria and cough. Severe adverse events are rare, with opportunistic infections being the main risk. The effect of rituximab on the levels of antibodies related to immunization, particularly in younger patients, may be minimized with concomitant use of intravenous immunoglobulin, thus reducing the risk of infections. ${ }^{1,6,7,8} \square$ 


\section{REFERENCES}

1. Hertl M, Zillikens D, Borradori L, Bruckner-Tuderman L, Burckhard H, Eming R, et al. Recommendations for the use of rituximab (anti-CD20 antibody) in the treatment of autoimmune bullous skin diseases. J Dtsch Dermatol Ges. 2008; 6:366-73.

2. Goebeler M, Herzog S, Bröcker EB, Zillikens D. Rapid response of treatment-resistant pemphigus foliaceus to the anti-CD20 antibody rituximab. $\mathrm{Br} \mathrm{J}$ Dermatol. 2003;149:899-901.

3. Daniel BS, Murrell DF, Joly P. Rituximab and its use in autoimmune bullous disorders. Dermatol Clin. 2011;29:571-5.

4. Arkfeld DG. The potential utility of B cell-directed biologic therapy in autoimmune diseases. Rheumatol Int. 2008;28:205-15.

5. Mouquet H, Musette P, Gougeon ML, Jacquot S, Lemercier B, Lim A, et al. B-cell depletion immunotherapy in pemphigus: effects on cellular and humoral immune responses. J Invest Dermatol. 2008;128:2859-69.

6. Cianchini G, Corona R, Frezzolini A, Ruffelli M, Didona B, Puddu P. Treatment of Severe Pemphigus with Rituximab: report of 12 cases and a review of the literature. Arch Dermatol. 2007:143:1033-8.

7. Matsukura S, Knowles SR, Walsh S, Shear NH. Effect of a single-cycle alternative dosing regimen for rituximab for recalcitrant pemphigus: a case series of 9 patients. Arch Dermatol. 2012;148:734-9.

8. Joly P, Mouquet $\mathrm{H}$, Roujeau JC, D'Incan M, Gilbert D, Jacquot S, et al . A single cycle of rituximab for the treatment of severe pemphigus. N Engl $J$ Med. 2007;357:545-52.

9. Diaz LA. Rituximab and pemphigus - a therapeutic advance. N Engl J Med. 2007;357:545-52.

10. Hertl M, Eming R, Borradori L. Rituximab (anti-CD20 monoclonal antibody)--ultimate or first choice in pemphigus? Dermatology. 2007;214: 275-7.

\author{
MAILING ADDRESS: \\ Isabela Soubhia Corral \\ Rua Dr. Cesário Motta Jr, 112 - Vila Buarque \\ 01221-020 - São Paulo - SP \\ Brazil \\ E-mail: isa_corral@hotmail.com
}

How to cite this article: Corral IS, Freitas THP, Aquino RTR, Koller DAS, Magliari MER, Muller H. Severe MultiResistant Pemphigus vulgaris: prolonged remission with a single cycle of Rituximab. An Bras Dermatol. 2013;88(4):639-42. 